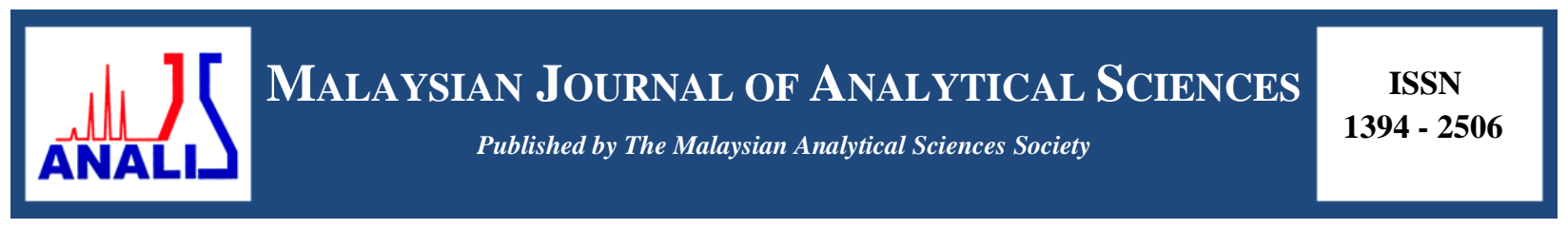

\title{
AN ENVIRONMENTALLY FRIENDLY METHOD FOR EXTRACTION OF PARABENS IN VARIOUS SAMPLES USING LOW VISCOSITY AND LOW CLOUD POINT TEMPERATURE SURFACTANT
}

\author{
(Satu Kaedah Mesra Alam untuk Pengekstrakan Paraben dalam Pelbagai Sampel Menggunakan \\ Surfaktan yang Rendah Kelikatan dan Rendah Suhu Titik Awan) \\ Norseyrihan Mohd Sohaimi ${ }^{1}$, Noorashikin Mohd Saleh ${ }^{2}$, Marinah Mohd Ariffin ${ }^{1}$, Shiuan Yih Beh ${ }^{2}$, Ruzita Ahmad $^{1}$ \\ ${ }^{1}$ School of Marine Science and Environment, Universiti Malaysia Terengganu, \\ 21030 Kuala Nerus, Terengganu, Malaysia \\ ${ }^{2}$ Chemical Engineering Programme, Research Centre for Sustainable Process Technology (CESPRO), \\ Universiti Kebangsaan Malaysia, 43600 UKM Bangi, Selangor, Malaysia \\ *Corresponding author: noorashikin@ukm.edu.my
}

Received: 8 January 2018; Accepted: 21 March 2018

\begin{abstract}
Cloud point extraction is developed using a low viscosity surfactant (Sylgard 309) coupled with HPLC-UV. It is a simple method for extraction of parabens in various samples. At the optimum conditions, the method developed achieves limit of detection and extraction recoveries in the range of $0.01 \mathrm{ppm}-0.02 \mathrm{ppm}$ and $68.5 \%-119.3 \%$, respectively. Linearity of the calibration curves in the range of $0.2-1.0 \mathrm{mg} / \mathrm{L}$. The correlation coefficient are achieved between 0.9995-0.9999. Each replicated samples are spiked with $1 \mathrm{mg} / \mathrm{L}$ of parabens. The results indicate that surfactant Sylgard 309 has a great potential for the extraction of organic pollutant in various samples.
\end{abstract}

Keywords: cloud point extraction, parabens, sylgard 309, simple method for extraction

\section{Abstrak}

Pengekstrakan titik awan dibangunkan menggunakan surfaktan yang mempunyai kelikatan yang rendah (Sylgard 309) digabungkan dengan KCPT-UV. Ini merupakan satu kaedah yang mudah untuk pemisahan paraben dalam pelbagai jenis sampel. Pada keadaan yang optimum, kaedah yang dibangunkan ini boleh mencapai had pengesanan dan perolehan semula pengekstrakan dalam julat $0.01 \mathrm{ppm}-0.02 \mathrm{ppm}$ dan $68.5 \%-119.3 \%$. Pekali korelasi yang dicapai adalah dalam julat $0.9995-$ 0.9999. Larutan piawai yang ditambahkan dalam sampel iaitu $1 \mathrm{mg} / \mathrm{l}$ paraben dalam setiap sampel replikat. Keputusan kajian menunjukkan bahawa surfaktan Sylgard 309 mempunyai potensi yang besar untuk diterokai bagi pengekstrakan pencemar 365rganic dalam pelbagai sampel.

Kata kunci: pengekstrakan titik awan, paraben, sylgard 309, kaedah ringkas untuk pengekstrakan

\section{Introduction}

Based on the study by Darbre and Harvey [1], the presence of free parabens (the formation of unconjugated forms and it considered as biological active) in human body tissues demonstrates that parabens are able to penetrate human skin intact without breakdown by esterase. Darbre et al. [2] measured concentrations of esters of paraben in human breast tumor and suggested that at least a proportion of the parabens present in daily used products such as cosmetic, food and pharmaceutical products can be absorbed and retained in the body tissue without undergo 


\section{Norseyrihan et al: AN ENVIRONMENTALLY FRIENDLY METHOD FOR EXTRACTION OF PARABENS IN VARIOUS SAMPLES USING LOW VISCOSITY AND LOW CLOUD POINT TEMPERATURE SURFACTANT}

hydrolysis [2]. Darbre and Harvey [1] reported that the estrogenic activity of ArP is higher than linear alkyl paraben which can promote breast cancer development. In fact, parabens are considered as endocrine disrupting chemicals (EDC) due to estrogens mimicker which increases the expression of genes and can cause human breast tumor cell [3]. It is suggested that more studies should be carried out for detailed evaluation of the potential of parabens. Concentration of parabens seldom exceeds $1 \%$ in products but it varies in different products [4]. Parabens do not persist in the environment since they will be degraded by photolysis in the air and biodegraded in water. The existence of the paraben are spread widely in the aquatic environment which it cannot easily be removed from the incoming water [5]. These phenomena occurs from swimmers using sunscreens and from sewage treatment plant [6].

There are a few methods that have been introduced to determine the parabens in water samples. The methods namely solid phase extraction [7], QuEChERS [8], dispersive liquid-liquid micro-extraction (DLLME) [9] and ionic liquid-based single-drop liquid phase micro-extraction (IL-based SDLME) [10]. Based on a study by Han et al. [11], these methods have their own specific disadvantages and not very suitable for determination of parabens in water samples. For example, due to high viscosity of surfactants, they cannot directly injected into CPE and dilution with solvent or water is necessary to complete the process of decreasing the viscosity. Each method has its own drawback such as QuEChERS has determination interference in the measurement; DLLME has poor reproducibility in extraction process due to its matrix where only the method only applicable for the simultaneous separation for intra-day repeatability [12], SDLPME is not very robust, and the droplets may be lost from the needle tip of the microsyringe during extraction.

As reported by Andersen [13], the available data of parabens are currently insufficient compared to other antimicrobial preservative compounds to support the assessment of their study. The concerns of the presence of paraben in human body tissue which develop to human breast cancer tissues become major interest in this research study [14]. With the continued use of paraben in the most of skincare cosmetics, foods and the residue from the industrial waste discharged to water, there is a need to carry out detailed evaluation regarding the potential of parabens. In fact, the information on the concentration of paraben in water samples could be helpful for risk assessment. In relation to this, the method of CPE is suitable method to extract parabens as it has a lot of advantages. It is simple, easy to carry out and rapid, low cost, environmental friendly and high sensitivity method of extraction in determining parabens from various samples without disturbing the neutrality of the environment [15].

\section{Reagents and solutions}

\section{Materials and Methods}

Sylgard 309 (3-(3-Hydroxypropyl)-heptamethyltrisiloxane ethoxylated acetate (>60\%) were purchased from Dow Corning (Shanghai, China). Sylgard 309 has the properties which are viscosity of $40 \mathrm{cST}$, cloud point temperature of $3^{\circ} \mathrm{C}$ and surface tension of 23 dynes/cm. The structure of Sylgard 309 is shown in Figure 1. Methylparaben (MeP, 99\%), Ethylparaben (EtP, 99\%), Propylparaben (PrP, 99.5\%) and Benzylparaben (ArP, 99\%) were purchased from Sigma Aldrich (USA). Sodium hydroxide $(\mathrm{NaOH}, 99 \%)$, hydrochloric acid $(\mathrm{HCl}, 37 \%)$, and acetonitrile (ACN, 99.9\%) used are analytical grade and were purchased from Merck (Germany). Deionized water was prepared through Millipore Milli-Q Plus water purification system. Stock standard solution of parabens (MeP, EtP, PrP, ArP) $(1000 \mathrm{mg} / \mathrm{L})$ were prepared in HPLC grade acetonitrile and stored at $4{ }^{\circ} \mathrm{C}$. The stock solutions were brought to ambient temperature prior to use.

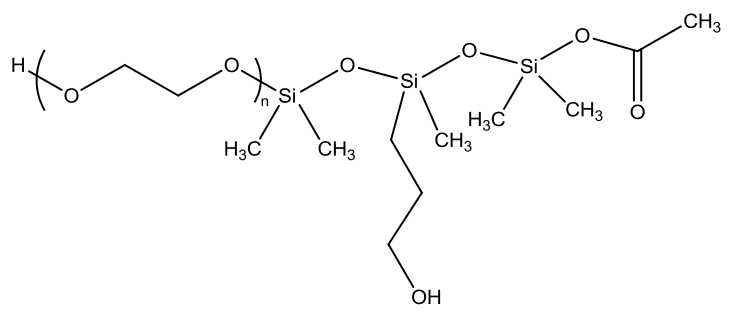

Figure 1. Structure of Sylgard 309 non-ionic surfactant 


\section{Instrumentations}

Extracted samples after undergo CPE were injected into Agilent Technologies with ultraviolet detector to test the presence of parabens. The HPLC-UV system is made up of pump, deggaser, auto injector, column oven, guard column, SUPELCO Ascentis and $\mathrm{C}_{18}$ column $(15 \mathrm{~cm} \times 4.6 \mathrm{~mm}, 0.5 \mu \mathrm{m}$, Sigma-Aldrich). Conditions of HPLC used for this separation are mobile phase was deionized water: acetonitrile $(50: 50, \mathrm{v} / \mathrm{v})$ with flow rate of $1.00 \mathrm{~mL} / \mathrm{min}$ and detection of $254 \mathrm{~nm}$.

\section{Cloud point extraction procedure}

A total of $2.5 \mathrm{~mL}$ of sample or standard solution containing the analyte $(1 \mathrm{mg} / \mathrm{L}), 0.2 \mathrm{~mL}$ of $20 \%$ surfactant (Sylgard 309) concentration (w/v), $0.5 \mathrm{~mL}$ of $1.5 \mathrm{M}$ of sodium sulphate $\left(\mathrm{Na}_{2} \mathrm{SO}_{4}\right)$, and $0.2 \mathrm{~mL}$ of water samples is mixed in a $10 \mathrm{~mL}$ centrifuge tube. The phase separation is placed in the sonicator for 5 minutes to induce separation into two phases. The cloud point temperature is determined by measuring the temperature of the solution when it became turbid after sonication. The upper layer of surfactant rich phase of the two layers formed is extracted using a long needle syringe and filtered with $0.45 \mu \mathrm{m}$ nylon filter membrane before injected into the HPLC-UV for analysis.

\section{Optimization of parameters for paraben extraction}

The extraction of paraben was conducted under one variable parameter with other parameter fixed as constant to obtain the optimum condition for the extraction. The parameters optimization include effect of $\mathrm{pH}$, water weight loss in the surfactant rich phase and interference ions.

For parameter effect of $\mathrm{pH}$, a series of sample at different $\mathrm{pH}(2,4,6,7,8,9,10,11,12$ and 14) was adjusted using dilute acid (hydrochloric acid) or dilute alkaline solution (sodium hydroxide) to obtain the desired $\mathrm{pH}$ solution with other parameters kept constant. For parameter water weight loss in the surfactant rich phase, a series of non-ionic surfactant Sylgard-309 were prepared at various concentrations of $10 \%(w / v), 20 \%(w / v), 30 \%(w / v), 40 \%(w / v)$ and $50 \%(w / v)$ using deionized water with other parameters kept constant.

For parameter interference ions, a series of sample at different type of ions $\left(\mathrm{Li}^{2+}, \mathrm{Mg}^{2+}, \mathrm{Br}^{-}, \mathrm{Cl}^{-}, \mathrm{SO}_{4}{ }^{2-}, \mathrm{NO}_{2}{ }^{-}, \mathrm{NH}_{4}{ }^{+}\right.$, $\mathrm{PO}_{4}^{3-}, \mathrm{F}^{-}, \mathrm{K}^{+}, \mathrm{NO}_{3}^{-}, \mathrm{Na}^{+}, \mathrm{Ca}^{2+}$ ) were prepared in $500 \mathrm{ppm}$ concentration in order to investigate selectivity with other parameters kept constant.

\section{Real sample preparation}

The pharmaceutical, personal care products such as shower cream, moisturizer, cleanser, make-up remover, body lotion, shampoo, mouth rinse, toothpaste, cough drop and herbal lotion and beverage samples such as drinking water, mineral water, mango juice, syrup cordial and carbonated drink were brought from local market in area of Terengganu, Malaysia. The pharmaceutical and personal care products were prepared in such way that $1 \mathrm{mg}$ of the sample was added into $100 \mathrm{ml}$ volumetric flask and top up with deionized water until it reaches the mark. For beverage sample, $1 \mathrm{ml}$ of sample is taken and dilute with deionized water with the ratio of 1:100. Then, all samples are filtered using a $0.45 \mu \mathrm{m}$ nylon membrane filter to remove suspended particulate matters and placed at $4{ }^{\circ} \mathrm{C}$ in the dark for storage. The samples are brought to ambient temperature when ready for analysis and $0.2 \mathrm{~mL}$ of each prepared samples is added to the CPE method preparation.

\section{Optimization of parameters: Effects of $\mathrm{pH}$}

\section{Results and Discussion}

$\mathrm{pH}$ plays an important factor in the CPE method to determine the extraction of an acidic or alkaline analyte in the aqueous solution. In order to determine the influence of the sample $\mathrm{pH}$ on the recovery of the studied analyte, an experiment was conducted over the range of $\mathrm{pH} 2-13$. The results are illustrated in Figure 2 which shown that the highest level extraction at $\mathrm{pH} 7$ for all studied parabens. The change in the extraction recoveries can be explained by considering the change in the charged of the parabens. At below $\mathrm{pH} \mathrm{3}$, paraben is in the protonated form, the extraction recovery of parabens in this form is low. This is because protonation of paraben may greatly weaken the hydrophobic interaction between paraben and the surfactant [16]. 


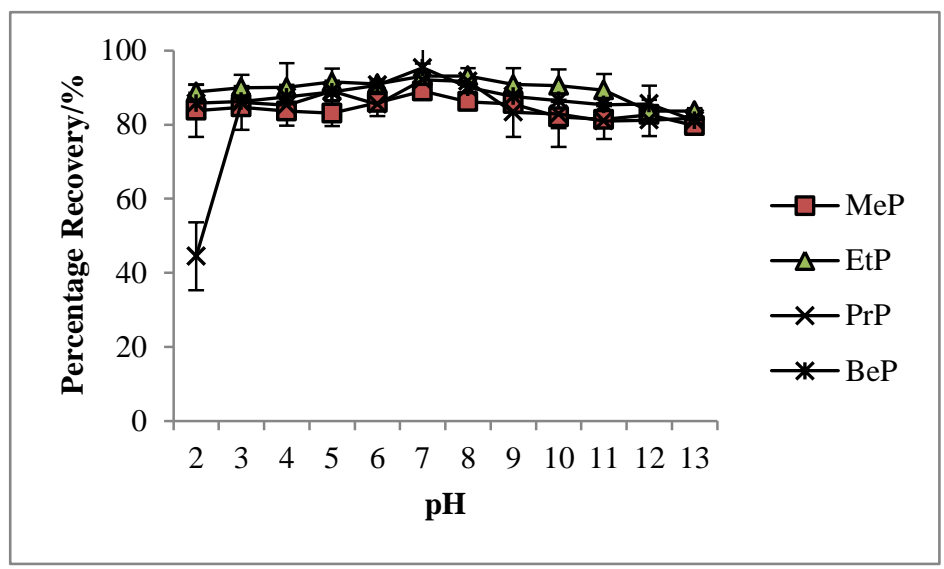

Figure 2. Effect of $\mathrm{pH}$ on the extraction recovery of parabens

Meanwhile, at $\mathrm{pH}$ 4-6, paraben exists mainly in the neutral form. There is slight increase in extraction recovery of paraben in this region as paraben loses its net positive charge due to the hydroxyl group becoming deprotonated. At $\mathrm{pH} 7$, paraben exists mostly in a negatively charged form because the hydroxyl group is now fully deprotonated. In this region, percentage recovery for all parabens increase. In CPE method, the hydrogen bonding, electrostatic attraction, and $\pi-\pi$ interaction could be the main interaction when paraben start to be deprotonated with the surfactant Sylgard 309.

From Figure 2, the decreasing trend of percentage recovery shown from $\mathrm{pH} 8-13$. This might be the reason that the percentage recovery of parabens is decreased at $\mathrm{pH} 8$ because all paraben compounds are fully transformed into alcohol and hydroxybenzoic acid [17]. Based on the previous research on the investigated of the parabens in water samples [18], the extraction performance reached a better level at $\mathrm{pH} 9$ for all the studied paraben. Thus, it can be concluding that $\mathrm{pH}$ plays an important role in determining the optimum conditions for paraben extraction $[19,20]$. Therefore, based on this optimization, we decide to use $\mathrm{pH} 7$ as the optimal condition in this study.

\section{Water weight loss in the surfactant rich phase}

Referring to Figure 3, the extraction of MeP shows the highest amount of water content at most $28 \%$ at low concentration of surfactant-rich phase of $10 \%(\mathrm{w} / \mathrm{v})$ surfactant concentration. This percentage of water content was reduced to almost $2 \%$ of water content at $50 \%(\mathrm{w} / \mathrm{v})$ surfactant concentration. This show a reduction of $26 \%$ from MeP when the surfactant concentration was increased from $10 \%(\mathrm{w} / \mathrm{v})$ to $50 \%(\mathrm{w} / \mathrm{v})$. The overall reduction for EtP is slightly lower than that of MeP which is $21 \%$ followed by $15 \%$ for ArP and then $12 \%$ for PrP.

Percentage of water content in the surfactant-rich phase is an important parameter as it will affect the preconcentration factor and the recovery of the analyte extracted. A high amount of water in the surfactant-rich phase will causes lower concentration of analytes to be extracted [21]. Thus, to have satisfactory extraction of analytes, the percentage of water content of in the surfactant-rich phase should be low. According to Yao and Yang [22], the performance of CPE is limited by the water content in the surfactant-rich phase. The lower amount of water content in the surfactant-rich phase will affect the concentration of analyte [19].

The trend that was shown in Figure 3 is increasing of surfactant concentration leads to decreasing of percentage water content. According to Sadeghi et al. [23], solute-solute interaction was greater than the interaction between surfactant with salt and water. When there is more hydrophilic surfactant in the solution, the solute-solute interaction will be more favorable and molecule of surfactant will interact with the surfactant than interacting with water molecules. This may give results of less percentage of water content in the surfactant-rich phase as less amount of water was detected. It is a good trend of water content corresponding to the surfactant concentration. This is because lesser water content in the surfactant-rich phase leading to a better performance of the surfactant in the 
CPE method. Thus, high percentage recovery of parabens will be extracted in the surfactant-rich phase. The presence of salt may be causes low water content in the surfactant-rich phase [24].

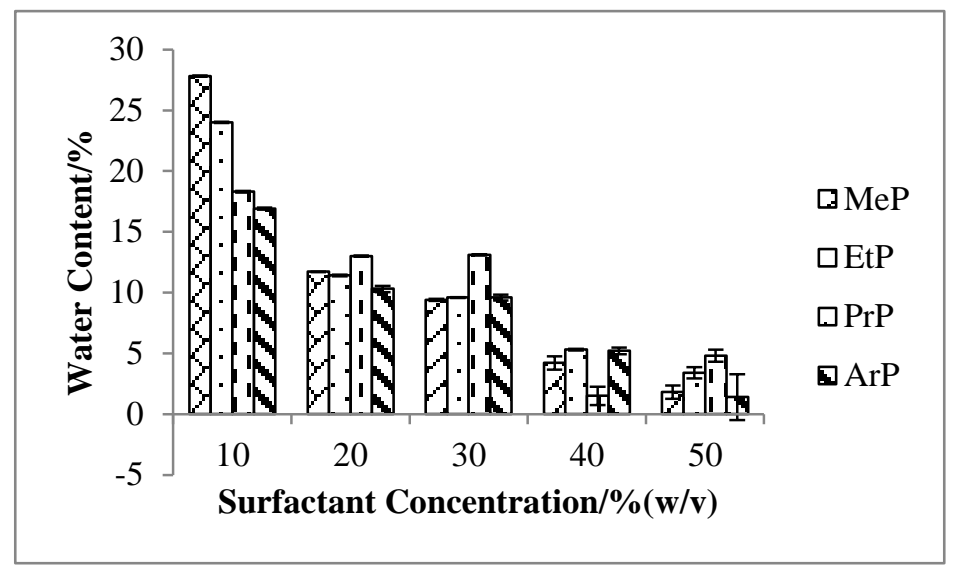

Figure 3. Water content in surfactant-rich phase using CPE method

\section{Interferences Study}

The efficiency of the proposed method in the extraction and pre-concentration of the parabens (MeP, EtP, PrP and ArP) ions in the presence of various cations and anions was examined by using solution containing $1.0 \mathrm{mg} / \mathrm{L} \mathrm{of}$ parabens with addition of various concentrations of potential interferences. The tolerance levels of each potentially interfering ion species was tested, and if interferences occurred, the ratio was reduced until it ceased. As can be seen from Table 1, several species did not interfere, showing that the method described is applicable to the analysis of parabens ions in different samples.

Table 1. Interferences of ions to the extraction recovery

\begin{tabular}{lcccc}
\hline Ion & MeP & EtP & PrP & BeP \\
\hline $\mathrm{Li}^{+}$ & 81.6 & 87.9 & 81.1 & 95.1 \\
$\mathrm{Mg}^{2+}$ & 80.9 & 83.9 & 82.4 & 98.7 \\
$\mathrm{Br}^{-}$ & 80.8 & 84.9 & 81.6 & 98.4 \\
$\mathrm{Cl}^{-}$ & 80.2 & 87.9 & 82.4 & 98.8 \\
$\mathrm{SO}_{4}{ }^{2-}$ & 80.3 & 88.6 & 81.6 & 92.7 \\
$\mathrm{NO}_{2}{ }^{-}$ & 80.4 & 87.9 & 82.1 & 95.3 \\
$\mathrm{NH}_{4}{ }^{+}$ & 80.7 & 87.0 & 84.5 & 96.9 \\
$\mathrm{PO}_{4}{ }^{3-}$ & 81.1 & 85.9 & 82.6 & 98.1 \\
$\mathrm{~F}^{-}$ & 80.8 & 85.3 & 82.0 & 94.7 \\
$\mathrm{~K}^{+}$ & 80.1 & 84.7 & 80.8 & 93.2 \\
$\mathrm{NO}_{3}{ }^{-}$ & 81.9 & 87.3 & 80.7 & 89.1 \\
$\mathrm{Na}^{+}$ & 80.5 & 84.1 & 88.1 & 94.6 \\
$\mathrm{Ca}^{2+}$ & 80.3 & 84.8 & 85.8 & 96.7 \\
\hline
\end{tabular}

\section{Analytical performance}

Quantitative parameters of CPE method such as linear range, correlation coefficients, limit of detection (LODs), limit of quantitation (LOQs) and regression equation were evaluated and summarized in Table 2. For the 


\section{Norseyrihan et al: AN ENVIRONMENTALLY FRIENDLY METHOD FOR EXTRACTION OF PARABENS IN VARIOUS SAMPLES USING LOW VISCOSITY AND LOW CLOUD POINT TEMPERATURE SURFACTANT}

quantification of the target analytes, an external standard calibration with five different concentration levels was used such as 0.2, 0.4, 0.6, 0.8 and $1.0 \mathrm{mg} / \mathrm{L}$ for all parabens MeP, EtP, PrP and ArP. For each level, three replicate extractions were performed under the optimal conditions. Linearity of the calibration curves was determined in the range of $0.2-1.0 \mathrm{mg} / \mathrm{L}$. the correlation coefficients are between $0.9995-0.9999$ respectively, suggesting that the linearity is satisfactory in the linear range of the analytes. The LODs and LOQs, based on signal-to-noise ratio $(\mathrm{S} / \mathrm{N})$ of 3:1 and 10:1, were obtained in the range of $0.01-0.02 \mathrm{mg} / \mathrm{L}$ and $0.04-0.07 \mathrm{mg} / \mathrm{L}$, respectively.

Table 2. Analytical performance of proposed method

\begin{tabular}{lllccc}
\hline Method & Paraben & Regression Equation $^{\mathrm{a}}$ & $\mathbf{R}^{\mathbf{2}}$ & $\begin{array}{c}\text { LOD } \\
(\mathbf{m g} / \mathbf{L})\end{array}$ & $\begin{array}{c}\text { LOQ } \\
(\mathbf{m g} / \mathbf{L})\end{array}$ \\
\hline & MeP & $\mathrm{y}=20.489 \mathrm{x}-0.2173$ & 0.9995 & 0.02 & 0.07 \\
& $\mathrm{EtP}$ & $\mathrm{y}=21.179 \mathrm{x}-0.4411$ & 0.9999 & 0.02 & 0.06 \\
& PrP & $\mathrm{y}=17.728 \mathrm{x}-0.4771$ & 0.9997 & 0.01 & 0.04 \\
$\mathrm{CPE}$ & ArP & $\mathrm{y}=16.151 \mathrm{x}-0.5682$ & 0.9999 & 0.02 & 0.07 \\
\hline
\end{tabular}

${ }^{\mathrm{a}}$ Peak area $=$ slope $\mathrm{x}[$ paraben concentration $(\mathrm{mg} / \mathrm{L})]+$ intercept

\section{Application of CPE in real samples}

Based on the optimized conditions, the performance of CPE method is tested on the pharmaceutical and personal care product samples in order to evaluate the accuracy and precision. To validate the method, three replicated samples are prepared. Each replicated samples are spiked with $1.0 \mathrm{mg} / \mathrm{L}$ of parabens. The relative standard deviation (RSD) and extraction recoveries of the spiked samples are shown in Table 3. As is obvious from Table 3, the recoveries for the spiked samples were found to be in the range of $68.5-119 \%$ with RSDs ranging from $0.10 \%$ to $5.11 \%$ in personal care product samples, the percentage recoveries are higher in MeP and $\operatorname{PrP}$ especially in moisturizer are $108.8 \%$ and $112.5 \%$, respectively. These result concluded that, the MeP and PrP are most commonly compounds are used in personal care product to increase preservative effect. The chromatogram of the pharmaceutical and personal care products is shown in Figure 4.

Table 3. Relative recoveries of parabens from various samples with spiked concentration $1 \mathrm{ppm}$ for each analyte

\begin{tabular}{|c|c|c|c|c|c|c|c|c|}
\hline \multirow{2}{*}{ Matrix } & \multicolumn{4}{|c|}{ Found $\left(\mu \mathrm{g} \mathrm{mL} L^{-1}, \pm R S D, n=3\right)$} & \multicolumn{4}{|c|}{ \% Relative Recovery } \\
\hline & MeP & EtP & PrP & ArP & MeP & EtP & PrP & ArP \\
\hline Shower Cream & $\mathrm{Nd}$ & $\mathrm{Nd}$ & $\mathrm{Nd}$ & $\mathrm{Nd}$ & 83.6 & 76.5 & 84.6 & 90.4 \\
\hline Moisturizer & $0.34( \pm 0.40)$ & $\mathrm{Nd}$ & $0.46( \pm 4.45)$ & $\mathrm{Nd}$ & 108.8 & 80.1 & 112.5 & 95.7 \\
\hline Cleanser & $0.33( \pm 1.04)$ & $0.02( \pm 0.24)$ & $\mathrm{Nd}$ & $\mathrm{Nd}$ & 86.3 & 82.1 & 86.2 & 91.9 \\
\hline Make-up Remover & $0.11( \pm 0.58)$ & $\mathrm{Nd}$ & $\mathrm{Nd}$ & $\mathrm{Nd}$ & 89.7 & 76.5 & 84.7 & 91.3 \\
\hline Body Lotion & $0.75( \pm 5.11)$ & $\mathrm{Nd}$ & $0.20( \pm 0.30)$ & $\mathrm{Nd}$ & 108.4 & 68.5 & 96.3 & 81.0 \\
\hline Shampoo & $0.15( \pm 1.13)$ & $0.02( \pm 0.42)$ & $\mathrm{Nd}$ & $\mathrm{Nd}$ & 80.3 & 75.1 & 82.6 & 89.8 \\
\hline Mouth Rinse & $\mathrm{Nd}$ & $\mathrm{Nd}$ & $\mathrm{Nd}$ & $\mathrm{Nd}$ & 83.3 & 76.1 & 86.1 & 91.6 \\
\hline Toothpaste & $0.45( \pm 1.13)$ & $0.01( \pm 1.42)$ & $\mathrm{Nd}$ & $\mathrm{Nd}$ & 80.4 & 72.8 & 80.9 & 88.7 \\
\hline Cough Drop & $\mathrm{Nd}$ & $\mathrm{Nd}$ & $0.001( \pm 0.10)$ & $\mathrm{Nd}$ & 81.6 & 73.0 & 81.7 & 87.9 \\
\hline Herbal Lotion & $\mathrm{Nd}$ & $0.18( \pm 0.58)$ & $\mathrm{Nd}$ & $\mathrm{Nd}$ & 81.0 & 74.5 & 80.9 & 119.3 \\
\hline Drinking Water & $\mathrm{Nd}$ & $\mathrm{Nd}$ & $\mathrm{Nd}$ & $\mathrm{Nd}$ & 85.3 & 77.0 & 85.0 & 88.3 \\
\hline Mineral Water & $\mathrm{Nd}$ & $\mathrm{Nd}$ & $1.07( \pm 0.78)$ & $\mathrm{Nd}$ & 85.3 & 78.1 & 89.6 & 99.2 \\
\hline Mango Juice & $\mathrm{Nd}$ & $\mathrm{Nd}$ & $\mathrm{Nd}$ & $\mathrm{Nd}$ & 84.6 & 75.8 & 85.5 & 90.3 \\
\hline Syrup Cordial & $\mathrm{Nd}$ & $\mathrm{Nd}$ & $\mathrm{Nd}$ & $\mathrm{Nd}$ & 87.5 & 78.8 & 85.5 & 89.2 \\
\hline Carbonated Drinking & $\mathrm{Nd}$ & $\mathrm{Nd}$ & $\mathrm{Nd}$ & $\mathrm{Nd}$ & 83.1 & 76.7 & 88.4 & 91.3 \\
\hline
\end{tabular}

RSD: Relative Standard Deviation, Nd: Non detected 

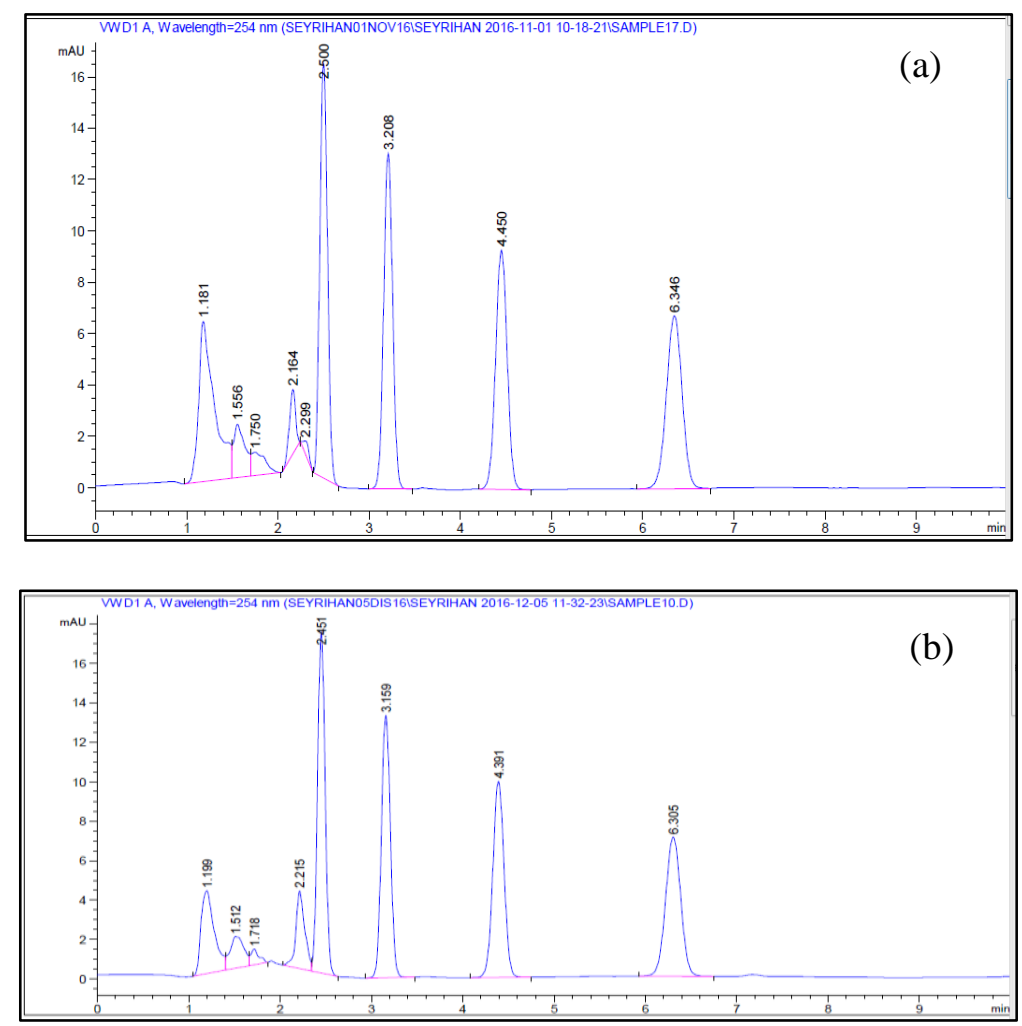

Figure 4. HPLC chromatograms of pharmaceutical and personal care products (a) shampoo (retention time; 2.50 $(\mathrm{MeP}) ; 3.209$ (EtP); $4.450(\mathrm{PrP})$ and $6.346(\mathrm{ArP})$ and (b) shower cream (retention time; $2.451(\mathrm{MeP})$; 3.159 (EtP); $4.391(\mathrm{PrP})$ and $6.305(\mathrm{ArP}))$.

From the chromatogram, the recoveries of pharmaceutical and personal care product have high peak intensity for all tested parabens, using these developed method also can separate the peaks easily without contaminated with other sample matrix. The peak area showed at high intensity, it is considered the presence of parabens compounds in pharmaceutical and personal care products can enter into the aquatic ecosystem via multiple pathways, including human excretion, unused drugs and products agricultural [25].

As can be seen, all the investigated compounds were found in the pharmaceutical and personal care products samples. The presence of parabens in greater amount in the pharmaceutical samples is due to the presence of chemicals substances in products. All the analytical results indicated that the simple CPE method proposed was very suitable for the simultaneous and rapid determination of parabens in pharmaceutical and personal care products samples without derivatization.

Nowadays, a variety of pharmaceuticals and personal care products (PPCPs) persist in natural freshwater resources [26].

\section{Comparison study}

The proposed method was compared with a variety of methods that have been reported recently in the literature for pre-concentration and determination of parabens in cosmetic products. Table 4 summarizes the main analytical information of the comparable methods reported for this type of samples. On the other hand, the percentage recoveries for proposed method achieved are higher compared with some of the method [27]. Besides that, the cost of acquision and maintenance of the system presented in this study are lower. The complexity of the analytical systems employed $[28,29]$ and sample pre-treatment requiring several steps $[29,30]$ of other methods described, can be compared with the ease of operation and low cost of CPE-HPLC-UV performance. Apparently, presented 


\section{Norseyrihan et al: AN ENVIRONMENTALLY FRIENDLY METHOD FOR EXTRACTION OF PARABENS IN VARIOUS SAMPLES USING LOW VISCOSITY AND LOW CLOUD POINT TEMPERATURE SURFACTANT}

method has low LODs, higher percentage recoveries, good RSD and these characteristics are comparable or even better than most of the other methods in Table 4.

Table 4. Comparison of the proposed method with other developed alternative for the determination of parabens in cosmetics

\begin{tabular}{llcccc}
\hline Method & Cosmetics Products & LOD & $\begin{array}{c}\text { RSD } \\
(\boldsymbol{\%})\end{array}$ & $\begin{array}{c}\text { Recover } \\
\mathbf{y}(\boldsymbol{\%})\end{array}$ & Ref \\
\hline SFE$^{\mathrm{a}} / \mathrm{HPLC}-\mathrm{MS}$ & Lanoline cream, Skin milk & $4.7-19.3 \mu \mathrm{gL}^{-1}$ & $<18.6$ & - & {$[27]$} \\
HPLC-CL $^{\mathrm{b}}$ & Wash-off cosmetics & $1.9-5.33 \mu \mathrm{gL}^{-1}$ & $<3.1$ & $93-106$ & {$[28]$} \\
HPLC-UV & Foam shampoo & $0.02-0.05 \mu \mathrm{gL}^{-1}$ & $<3.2$ & $98-105$ & {$[30]$} \\
FIA $^{\mathrm{c}}$-SPE-MEKC & Gel, Lotions, water/oil based & $0.07-0.1 \mathrm{mgL}^{-1}$ & $<2.3$ & $93-102$ & {$[29]$} \\
& Creams & & & & \\
SPE-HPLC-CAD & Cream, Shampoo, Make-up, & $0.5-2.1 \mathrm{mgL}^{-1}$ & $<3.8$ & $90-104$ & {$[7]$} \\
& Lotions & & & \\
CPE-HPLC-UV & Shower Cream, Moisturizer, & $0.01-0.02 \mathrm{mgL}^{-1}$ & $<6.0$ & $68-112$ & $\begin{array}{l}\text { This } \\
\text { work }\end{array}$ \\
& Cleanser, Make-up Remover, & & & & \\
\hline
\end{tabular}

${ }^{\mathrm{a}} \mathrm{SFE}$ : supercritical fluid extraction, ${ }^{\mathrm{b}} \mathrm{CL}$ : chemiluminescene and ${ }^{\mathrm{c}} \mathrm{FIA}$ : flow injection analysis

\section{Conclusion}

In this study, it shows that the method of CPE paired with non-ionic surfactant Sylgard 309 is an effective extraction method of parabens in various types of samples. Under the optimal conditions, the determination of four widely used parabens (MeP, EtP, PrP and ArP) using the combination of CPE and HPLC-UV indicates excellent LOD as low as 0.01-0.02 ppm. This CPE method have advantages such as simple, easy to carry out and fast as the extraction time is just 5 minutes. This method uses a minimum amount of organic solvents consequently leads to less organic waste, lower cost and even more environmental friendly as the surfactant used are less toxic. It also produces a high sensitivity method of extraction if compared with other proposed methods. CPE application to a wide range of pharmaceutical and personal care products and beverages samples matrices analysis without a significant variation in the sample preparation and extraction procedures shows that this method could be applied for the determination of parabens in various samples in laboratories analysis.

\section{Acknowledgement}

The authors wish to thank Department of Analytical and Environmental Chemistry, School of Marine and Environmental Sciences, Universiti Malaysia Terengganu for the facilities provided.

\section{References}

1. Darbre, P. D. and Harvey, P. W. (2008). Paraben esters: Review of recent studies of endocrine toxicity, absorption, esterase and human exposure, and discussion of potential human health risks. Journal Applied Toxicology, 28(5): 561-578.

2. Darbre, P. D., Aljarrah, A., Miller, W. R., Coldham, N. G., Sauer, M. J. and Pope, G. S. (2004). Concentrations of parabens in human breast tumours. Journal of Applied Toxicology, 24(1): 5-13.

3. Calafat, A. M., Ye, X., Wong, L.Y., Bishop, A. M. and Needham, L. L. (2010). Urinary concentrations of four parabens in the us population: Nhanes 2005-2006. Environmental Health Perspective, 118(5): 679.

4. Soni, M., Carabin, I., and Burdock, G. (2005). Safety assessment of esters of p-hydroxybenzoic acid (parabens). Food and Chemical Toxicology, 43 (7): 985-1015.

5. Jonkers, N., Kohler, H. P. E., Dammshäuser, A. and Giger, W. (2009). Mass flows of endocrine disruptors in the glatt river during varying weather conditions. Environmental Pollution, 157(3): 714-723. 
6. Peng, X., Yu, Y., Tang, C., Tan, J., Huang, Q., and Wang, Z. (2008). Occurrence of steroid estrogens, endocrinedisrupting phenols, and acid pharmaceutical residues in urban riverine water of the pearl river delta, south china. Science of the Total Environment, 397 (1): 158-166.

7. Márquez-Sillero, I., Aguilera-Herrador, E., Cárdenas, S. and Valcárcel, M. (2010). Determination of parabens in cosmetic products using multi-walled carbon nanotubes as solid phase extraction sorbent and corona-charged aerosol detection system. Journal of Chromatography A, 1217(1):1-6.

8. Plassmann, M. M., Schmidt, M., Brack, W. and Krauss, M. (2015). Detecting a wide range of environmental contaminants in human blood samples-combining quechers with LC-MS and GC-MS methods. Analytical Bioanaytical Chemistry, 407 (23): 7047-7054.

9. Jain, R., Mudiam, M. K. R., Chauhan, A., Ch, R., Murthy, R., and Khan, H. A. (2013). Simultaneous derivatisation and preconcentration of parabens in food and other matrices by isobutyl chloroformate and dispersive liquid-liquid microextraction followed by gas chromatographic analysis. Food Chemistry, 141(1): 436-443.

10. Guo, X., Yin, D., Peng, J. and Hu, X. (2012). Ionic liquid-based single-drop liquid-phase microextraction combined with high-performance liquid chromatography for the determination of sulfonamides in environmental water. Journal of Separation Science, 35(3): 452-458.

11. Han, J., Wang, Y., Liu, Y., Li, Y., Lu, Y., Yan, Y. and Ni, L. (2013). Ionic liquid-salt aqueous two-phase extraction based on salting-out coupled with high-performance liquid chromatography for the determination of sulfonamides in water and food. Analytical and Bioanaytical Chemistry, 405(4): 1245-1255.

12. Wen, Y., Li, J., Zhang, W., and Chen, L. (2011). Dispersive liquid-liquid microextraction coupled with capillary electrophoresis for simultaneous determination of sulfonamides with the aid of experimental design. Electrophoresis, 32 (16): 2131-2138.

13. Andersen, F. A. (2008). Final amended report on the safety assessment of methylparaben, ethylparaben, propylparaben, isopropylparaben, butylparaben, isobutylparaben, and benzylparaben as used in cosmetic products. International Journal Toxicology, 27: 1-82.

14. Noorashikin, M. S., Farhanini, Y., Karthi, S. and Ruzita, A. (2017). Detecting parabens in environmental water samples. International News on Fats, Oils and Related Materials, 28: 16-17.

15. Norseyrihan, M. S., Noorashikin, M. S. and Hasrina, H. Z. (2017). Cloud point extraction of parabens from water samples. Advances in medicine and biology. Nova Science Publisher, Inc., New York: pp. 259-276.

16. Yin, X.-B., Guo, J.-M. and Wei, W. (2010). Dual-cloud point extraction and tertiary amine labeling for selective and sensitive capillary electrophoresis-electrochemiluminescent detection of auxins. Journal Chromatography A, 1217 (8): 1399-1406.

17. Angelov, T., Vlasenko, A. and Tashkov, W. (2008). HPLC determination of pka of parabens and investigation on their lipophilicity parameters. Journal of Liquid Chromatography \& Related Technologies, 31: 188-197.

18. Noorashikin, M. S., Raoov, M., Mohamad, S. and Abas, M. R. (2013). Cloud point extraction of parabens using non-ionic surfactant with cylodextrin functionalized ionic liquid as a modifier. International Journal of Molecular Sciences, 14(12): 24531-24548.

19. Noorashikin, M. S., Nur Nadiah, A. B., Nurain, I., Siti Aisyah, A. A., and Siti Zulaika, M. R. (2016). Determination of phenol in water samples using cloud point extraction and uv spectrophotometry. Desalination and Water Treatment, 57(33): 15486-15494.

20. Noorashikin, M. S., Mohamad, S. and Abas, M. R. (2016). Determination of parabens in water samples by cloud point extraction and aqueous two-phase extraction using high-performance liquid chromatography. Desalination and Water Treatment, 57(47): 22353-22361.

21. Norseyrihan, M. S., Noorashikin, M. S., Adibah, M. S. N. and Yusoff, F. (2016). Cloud point extraction of methylphenol in water samples with low viscosity of non-ionic surfactant sylgard 309 coupled with highperformance liquid chromatography. Separation Science and Technology, 51(14): 2386-2393.

22. Yao, B. and Yang, L. (2008). Equilibrium partition of polycyclic aromatic hydrocarbons in cloud point extraction with a silicone surfactant. Journal of Colloid and Interface Science, 319(1): 316-321.

23. Sadeghi, R., Ebrahimi, N. and Mahdavi, A. (2012). Thermodynamic studies of the ionic liquid 1-hexyl-3methylimidazolium chloride [c $6 \mathrm{mim}][\mathrm{cl}]$ in polyethylene glycol aqueous solutions. The Journal of Chemical Thermodynamics, 47: 48-55.

24. Noorashikin, M. S., Mohamad, S. and Abas, M. R. B. (2013). Cloud point extraction (CPE) of parabens using nonionic surfactant phase sepration. Separation Science and Technology, 48: 1675-1681. 
Norseyrihan et al: AN ENVIRONMENTALLY FRIENDLY METHOD FOR EXTRACTION OF PARABENS

IN VARIOUS SAMPLES USING LOW VISCOSITY AND LOW CLOUD POINT

TEMPERATURE SURFACTANT

25. Rosi-Marshall, E. J. and Royer, T. V. (2012). Pharmaceutical compounds and ecosystem function: An emerging research challenge for aquatic ecologists. Ecosystems, 15(6): 867-880.

26. Zhang, J., and Ma, P. X. (2013). Cyclodextrin-based supramolecular systems for drug delivery: Recent progress and future perspective. Advanced Drug Delivery Reviews, 65(9): 1215-1233.

27. Lee, M.-R., Lin, C.-Y., Li, Z.-G. and Tsai, T.-F. (2006). Simultaneous analysis of antioxidants and preservatives in cosmetics by supercritical fluid extraction combined with liquid chromatography-mass spectrometry. Journal of Chromatography A, 1120 (1-2): 244-251.

28. Zhang, Q., Lian, M., Liu, L. and Cui, H. (2005). High-performance liquid chromatographic assay of parabens in wash-off cosmetic products and foods using chemiluminescence detection. Analytica Chimica Acta, 537(1): 31-39.

29. Han, F., He, Y.-Z. and Yu, C.-Z. (2008). On-line pretreatment and determination of parabens in cosmetic products by combination of flow injection analysis, solid-phase extraction and micellar electrokinetic chromatography. Talanta, 74(5): 1371-1377.

30. Labat, L., Kummer, E., Dallet, P. and Dubost, J. P. (2000). Comparison of high-performance liquid chromatography and capillary zone electrophoresis for the determination of parabens in a cosmetic product. Journal of Pharmaceutical and Biomedical Analysis, 23(4): 763-769. 